\title{
HASIL BELAJAR BAHASA INDONESIA TEMA PAHLAWANKU MENGGUNAKAN REWARD KELAS IV SDN 024 SAMARINDA UTARA
}

\section{RESULT OF LEARNING BAHASA INDONESIA MY HEROES THEME USING REWARDS CLASS IV SDN 024 NORTH SAMARINDA}

\author{
Hani Subakti, Laurensius Padan \\ Universitas Widya Gama Mahakam Samarinda \\ Universitas Widya Gama Mahakam Samarinda \\ Jalan Wahid Hasyim 2 No. 28 Samarinda \\ Pos-el: hanisubakti@uwgm.ac.id, laurensiuspadan@gmail.com
}

*) Naskah diterima: 24 Maret 2020; direvisi: 17 April 2020; disetujui: 23 Mei 2020

\begin{abstract}
Abstrak
Penelitian tindakan kelas (PTK) ini memiliki tujuan mengetahui hasil belajar bahasa Indonesia siswa kelas IV SDN 024 Samarinda Utara. Dalam penelitian ini telah terjadi peningkatan yang signifikan pada hasil belajar bahasa Indonesia tema pahlawanku dengan menggunakan reward pada kelas IV SDN 024 Samarinda Utara. Penelitian ini sudah dilaksanakan sebanyak dua siklus. Tahap pelaksanaan setiap siklus terdiri atas perencanaan, pelaksanaan, pengamatan, dan refleksi. Teknik pengumpulan data menggunakan observasi, tes, wawancara, dan dokumentasi. Hasil akhir penelitian menunjukan bahwa pada siklus I hasil belajar siswa dengan nilai tes rata-rata 69,5 dengan persentase ketuntasan $60 \%$ dan persentase tidak tuntas, yaitu $40 \%$. Sementara itu, pada siklus II hasil belajar siswa dengan nilai tes rata-rata 81,3 meningkat dengan persentase ketuntasan $86,7 \%$ dan persentase tidak tuntas hanya $13,3 \%$. Berdasarkan hasil penelitian tersebut, dapat disimpulkan bahwa strategi reward dapat meningkatkan hasil belajar bahasa Indonesia tema pahlawanku pada siswa kelas IV SDN 024 Samarinda Utara.
\end{abstract}

Kata kunci: hasil belajar, bahasa Indonesia, tema pahlawanku, reward

\begin{abstract}
This class action research (CAR) has the purpose of knowing the outcome of learning outcomes of grade IV students in SDN 024 North Samarinda. In this study there has been a significant increase in the results of the Indonesian language learning hero theme by using the reward on class IV SDN 024 North Samarinda. This research has been implemented by two cycles. The implementation stage of each cycle consists of planning, implementation, observation, and reflection. Data collection techniques using observation, tests, interviews, and documentation. The final result of the study showed that the students study results with an average test value of 69.5 with a percentage of $60 \%$ and an incomplete percentage of $40 \%$. While in the cycle II students study results with an average test value of 81.3 increased with a percentage of $86.7 \%$, the percentage was not completed by only $13.3 \%$. Based on the results of the study, it can be concluded that the reward strategy can improve the outcome of learning Indonesian theme heroes in grade IV students SDN 024 North Samarinda.
\end{abstract}

Keywords: learning results, bahasa Indonesia, my hero theme, reward 


\section{PENDAHULUAN}

Pendidikan merupakan salah satu pembinaan termutakhir bagi peradaban manusia untuk menjadi warga negara yang baik sesuai dengan perkembangan akal pikiran manusia yang senantiasa mengalami pertumbuhan, perkembangan, dan perubahan (Anwar, 2017). Dari definisi tersebut, dapat disimpulan bahwa pendidikan merupakan proses pengembangan individu dan pengembangan karakter seseorang yang menjadikan warga negara menjadi baik dengan menjunjung keluhuran. Di sisi lain, dapat menanamkan kaidah-kaidah atau nilai-nilai sebagai kesempurnaan kehidupan seseorang dengan kepribadian yang mandiri serta rasa tanggung jawab bermasyarakat, berbangsa, dan bernegara.

Tujuan pendidikan dan pembelajaran itu sendiri dapat tercapai bila kualitas guru dapat mendukung dalam proses pendidikan dan pembelajaran di sekolah (Susanto, 2016). Apabila hal ini tidak menjadi faktor dominan yang utama, semua kegiatan yang dilakukan tidak akan mencapai hasil yang diharapkan sesuai dengan rencana yang telah disusun. Seorang guru atau pendidik dituntut dapat membuat pembelajaran yang menarik, efektif, dan efisien.

Keberhasilan proses pembelajaran di dalam kelas sangat dipengaruhi oleh aktivitas guru dan siswanya. Guru dan siswa harus selalu bekerja sama dalam setiap proses pembelajaran (Subakti, 2017:91). Akan tetapi, banyak faktor yang menjadi penghambat, di antaranya, letak lingkungan sekolah yang berdekatan dengan rumah penduduk, situasi lingkungan sekitar sekolah yang tidak kondusif, serta adanya anak-anak di luar lingkungan sekolah bermain di dalam lingkungan sekolah. Hal ini disinyalisasi mengganggu konsentrasi belajar siswa dan menyebabkan siswa kurang bersemangat dalam belajar sehingga tidak mencapai kriteria ketuntasan minimal (KKM) yang diharapakan.

Ini semua terlihat dari hasil observasi awal penelitian yang telah dilaksanakan sebelumnya. Data yang diperoleh menunjukkan rata-rata persentase hasil evaluasi harian siswa di SDN 024 Samarinda Utara berada di bawah standar kriteria ketuntasan minimal (KKM) dengan nilai hanya di sekitar $60--70 \%$. Nilai tersebut masih di bawah kriteria ketuntasan minimal (KKM) yang menjadi standar acuan nilai di atas $70 \%$ sebagai batas nilai yang mencukupi standar kriteria ketuntasan minimal (KKM) di SDN 024 Samarinda Utara. Atas dasar tersebut, peneliti mencoba menggunakan reward sebagai cara untuk meningkatkan motivasi dan minat belajar siswa.

Dari permasalahan tersebut, penulis tertarik untuk melaksanakan penelitian yang berjudul "Hasil Belajar Bahasa Indonesia Tema Pahlawanku dengan Menggunakan Reward Kelas IV SDN 024 Samarinda Utara.

\section{LANDASAN TEORI}

Reward adalah media atau alat penilaian yang bersifat positif terhadap hasil belajar siswa. Peranan reward sendiri dalam proses belajar mengajar ataupun pengajaran cukup penting terutama sebagai faktor eksternal yang memengaruhi danmengarahkan perilaku siswa itu sendiri (Hamalik, 2013). Hal ini berdasarkan pertimbangan logis untuk menimbulkan motivasi belajar serta memengaruhi perilaku positif dalam kehidupan siswa.

Pembelajaran bahasa Indonesia di sekolah dasar sangatlah penting dan memiliki alasan kuat untuk dilakukan. Hal ini dikarenakan bahasa Indonesia merupakan sarana pendukung ilmu dan teknologi yang terus berkembang. Salah satu tujuan mata pelajaran bahasa Indonesia di sekolah dasar adalah agar peserta didik memiliki kemam- 
puan berkomunikasi secara efektif dan efisien (Sutrisno, 2019:162).

Siswa yang berada pada jenjang pendidikan dasar adalah mereka yang sedang menjalani tahap perkembangan masa kanakkanak dan memasuki masa remaja awal. Apabila mereka mengakhiri pendidikannya di sekolah dasar, mereka telah berada pada tahap perkembangan yang memasuki masa remaja awal. Pada masa ini siswa diharapkan memperoleh pengetahuan bahasa Indonesia yang dipandang sangat penting bagi pendidikan jenjang selanjutnya (Hidayah, 2015:192).

Sugiyono (2015) menjelaskan bahwa desain penelitian tindakan kelas (PTK) memiliki tujuan meningkatkan kualitas pembelajaran serta membantu memberdayakan guru dalam memecahkan masalah pembelajaran yang ada di sekolah. Sementara itu, tujuan utama dari penelitian ini berupaya untuk memperbaiki praktik pembelajaran yang selama ini dirasa kurang baik agar menjadi lebih efektif dan efisien. Untuk mencapai tujuan tersebut, pembelajaran di dalam kelas harus memiliki suasana belajar yang nyaman bagi guru dan peserta didik itu sendiri.

Arikunto, Suhardjono, dan Supardi (2016) mendefinisikan model penelitian tindakan kelas (PTK) merupakan penelitian eksperimen yang berulang atau eksperimen berkelanjutan, meskipun tidak selalu demikian adanya. Apabila guru atau pendidik tidak puas dengan hasil pembelajarannya dan berkeinginan mengubah pembelajaran itu dengan model yang sifatnya baru, dipersilakan mencobanya tidak hanya satu kali saja, tetapi berulangulang sehingga penelitian itu sering disebut penelitian tindakan.

Daryanto (2011) mendeskripsikan bahwa siklus penelitian tindakan kelas (PTK) tidak bersifat instan, cepat jadi, ataupun langsung memberikan perubahan dalam waktu yang relatif singkat, tetapi sesuai dengan tahapan atau siklus yang dijalankan. Di dalam Kamus Besar Bahasa Indonesia $V$ dijelaskan bahwa siklus adalah putaran waktu yang di dalamnya terdapat rangkaian kejadian yang berulang-ulang secara tetap dan teratur (Badan Pengembangan dan Pembinaan Bahasa, 2016). Dalam hal ini, tahapan-tahapan yang merupakan proses dari sebuah perbaikan harus dilakukan. Dengan demikian, dapat disimpulkan bahwa siklus bermakna berproses dan berulang dan tidak dapat dilakukan hanya dalam satu kali tindakan, tetapi merupakan tindakan yang berkelanjutan sehingga memberikan perubahan dalam tiap proses dan hasil pembelajaran di kelas.

\section{METODE PENELITIAN}

Penelitian ini merupakan penelitian tindakan kelas (PTK). Tempat penelitian penelitian dilaksanakan di kelas IV SDN 024 Samarinda Utara yang beralamat di Jalan Bengkuring Raya Blok C, Kelurahan Sempaja Selatan, Kecamatan Samarinda Utara, Kota Samarinda. Sementara itu, waktu pelaksanakan penelitian, yaitu bulan September sampai dengan Oktober pada semester ganjil tahun pembelajaran 2019/ 2020. Subjek penelitian dalam penelitian tindakan kelas (PTK) ini, yaitu siswa kelas IV SDN 024 Samarinda Utara.

Penelitian tindakan kelas (PTK) ini dilakukan melalui empat tahap, yaitu perencanaan, pelaksanaan, pengamatan, dan refleksi. Penelitian yang dilakukan terdiri atas 2 siklus, yang setiap siklus terdiri atas 3 kali pertemuan. Pertemuan pertama dan kedua untuk penyampaian materi, sedangkan pertemuan ketiga dilaksanakan untuk pemberian tes pada siswa.

Pelaksanaan penelitian tindakan kelas (PTK) dimulai dengan siklus I yang terdiri atas empat bagian. Apabila sudah diketahui 
letak keberhasilan dan hambatan dari tindakan yang dilaksanakan pada siklus pertama tersebut, peneliti menentukan rencana untuk siklus kedua. Kegiatan pada siklus II hampir sama dengan kegiatan sebelumnya yang ditujukan untuk menyakinkan hasil. Akan tetapi, umumnya kegiatan yang dilakukan pada siklus II mempunyai berbagai tambahan perbaikan dari tindakan terdahulu yang tentu saja ditujukan untuk perbaikan berbagai hambatan dan kesulitan yang ditentukan dalam siklus I.

Wijaya (2013) menjelaskan pentingnya teknik pengumpulan data dengan tujuan memperoleh data kongkret diperlukan dalam penelitian ini, peneliti menggunakan beberapa teknik, yaitu sebagai berikut.

Observasi atau pengamatan merupakan cara yang digunakan untuk mengumpulkan data, dalam hal ini peneliti menggunakan observasi partisipatif. Peneliti melakukan pengamatan dan ikut berpartisipasi dalam kegiatan dengan sumber data, yaitu peserta didik. Observasi merupakan pengamatan langsung menggunakan alat indra atau instrumen sebagai alat bantu pengindraan suatu subjek atau objek. Dalam teknik pengumpulan data ini, peneliti menggunakan tes pengukuran secara keseluruhan. Dalam hal ini mencangkup sikap, persepsi, pendapat, dan pengalaman siswa.

Tes sebagai instrumen yang baik digunakan dalam penelitian tindakan kelas (PTK). Dalam penelitian tindakan kelas (PTK), salah satu yang diukur adalah aspek psikologis yang dapat berupa prestasi atau hasil belajar, minat bakat, sikap kecerdasan, reaksi motorik, dan berbagai aspek kepribadian lainnya. Tes yang diberikan adalah tes tertulis dengan bentuk soal uraian dengan jumlah 10 soal yang sudah disiapkan oleh peneliti dalam melakukan kegiatan tes tersebut.

Wawancara merupakan komunikasi verbal atau percakapan yang bertujuan mendapatkan informasi terkait dan eksklusif. Mengumpulkan data dengan melakukan tanya jawab yang dilakukan berlandaskan pada tujuan penelitian yang dilakukan kepada siswa yang hadir secara fisik dalam tanya jawab. Wawancara ini dilakukan pada peserta didik setelah mengikuti pembelajaran. Untuk itu, peneliti menyiapkan sebuah pertanyaan yang sudah dipersiapkan, yaitu catatan dengan disertai kamera gawai untuk memotret pada saat peneliti melakukan pembicaraan dengan sumber data.

Dokumentasi adalah salah satu cara mencari data dengan melihat benda-benda tertulis, berupa catatan harian/lapangan, dokumen-dokumen, notulen, nilai siswa, dan sebagainya. Dokumen ini sebagai bahan pendukung untuk memperkuat hasil penelitian.

Teknik analisis data yang diperoleh dari observasi dan evaluasi langsung dianalisis sesuai dengan indikator. Hal ini dilakukan untuk mengetahui permasalahan dalam penelitian pada dua siklus. Perhitungan nilai menggunakan rumus sebagai berikut.

Perhitungan rata-rata nilai siswa:

$$
\mathrm{X} \frac{\sum \mathrm{x}}{\sum \mathrm{N}}
$$

\section{Keterangan:}

$\mathrm{X}=$ nilai rata-rata

$\sum \mathrm{x}=$ jumlah nilai siswa

$\sum \mathbf{N}=$ jumlah siswa yang mengikuti tes (Sudjana, 2016)

Perhitungan ketuntasan belajar dalam penelitian ini terdapat dua kategori ketuntasan belajar, yaitu secara individu dan klasikal. Ketuntasan belajar secara individual didapat dari kriteria ketuntasan minimal (KKM) untuk pembelajaran yang ditetapkan sekolah, yaitu siswa dinyatakan tuntas jika telah mendapatkan nilai sekurang-kurang- 
nya 70 dan jika di bawah 70 dinyatakan belum tuntas. Sementara itu, ketuntasan belajar secara klasikal, yaitu mengukur tingkat keberhasilan ketuntasan belajar siswa secara menyeluruh. Untuk menghitung persentase ketuntasan belajar klasikal digunakan rumus:

$\mathrm{P}=\frac{\sum \text { jumlah siswa yang mendapat nilai }}{\sum \text { jumlah siswa mengikuti tes }} \times 100 \%$

Keterangan:

$\mathrm{P}=$ persentase ketuntasan

Sudjana, (2016)

Ketuntasan belajar klasikal dinyatakan berhasil jika persentase siswa yang tuntas belajar atau siswa yang mendapat nilai e"70 jumlahnya lebih besar atau sama dengan $80 \%$ dari jumlah siswa seluruhnya. Hasil analisis ini digunakan sebagai bahan refleksi untuk melakukan perencanaan lanjutan dalam pertemuan dan siklus berikutnya. Hasil analisis juga dijadikan sebagai bahan refleksi dalam memperbaiki rancangan pembelajaran atau bahkan sebagai bahan pertimbangan dalam penentuan metode pembelajaran yang tepat.

\section{Indikator Keberhasilan}

Indikator keberhasilan dalam penelitian ini dapat diukur dari meningkatnya hasil belajar siswa. Peningkatan tersebut adalah $80 \%$ dari jumlah keseluruhan siswa di dalam kelas dengan kriteria ketuntasan minimum (KKM) yang sudah ditentukan oleh sekolah.

\section{HASIL DAN PEMBAHASAN}

Penelitian tindakan kelas (PTK) dilaksanakan di SDN 024 Samarinda Utara yang beralamat di Jalan Bengkuring Raya Blok C Kelurahan Sempaja Selatan, Kecamatan Samarinda Utara, Kota Samarinda. Subjek penelitian adalah siswa kelas IV dengan jumlah siswa 30 orang yang terdiri atas 16 siswa laki-laki dan 14 siswa perempuan. pelaksanaanya dilakukan pada semester ganjil tahun pembelajaran 2019/2020.

\section{Siklus I}

Siklus I terdiri atas 3 kali pertemuan di kelas. Waktu pembelajaran yang digunakan di setiap pertemuan adalah 70 menit, dengan keseluruhan waktu pembelajaran yang digunakan pada siklus I adalah 210 menit. Dalam penelitian ini, siklus I dilaksanakan dengan empat tahapan, yaitu sebagai berikut.

\section{Perencanaan}

Berdasarkan hasil nilai yang dilaksanakan sebelumnya, nilai siswa kelas IV dari 30 siswa yang mencapai kriteria ketuntasan minimal (KKM) adalah 10 orang siswa $(14.2 \%)$, sedangkan 20 orang $(85.8 \%)$ belum mencapai kriteria ketuntasan minimal (KKM). Oleh karena itu, dilakukan penelitian menggunakan reward untuk meningkatkan hasil belajar Bahasa Indonesia kelas IV dengan menyusun langkah-langkah perencanaan pembelajaran sebagai berikut:

a. menyiapkan rencana pelaksanaan pembelajaran (RPP),

b. menyiapkan soal evaluasi untuk melihat tingkat hasil belajar pada siklus I,

c. menyiapkan lembar wawancara,

d. menyiapkan lembar observasi, dan

e. menyiapkan reward.

\section{Pelaksanaan}

Pada tahap pelaksanaan ini dilakukan 3 kali pertemuan, yaitu pertemuan satu dan dua menyampaikan materi, sedangkan pertemuan ketiga melakukan tes hasil belajar siswa. Tindakan siklus I dilaksanakan tiga kali pertemuan, dua kali pertemuan untuk mengajarkan materi dan pertemuan ketiga tes. Selama pembelajaran, ada beberapa masalah yang dihadapi pada siklus I, yaitu siswa masih banyak bercerita 
di dalam kelas, tidak memperhatikan penjelasan peneliti, berjalan-jalan ke bangku temannya, dan izin berkali-kali ke toilet.

Pada saat peneliti menjelaskan kontrak pembelajaran dan akan memberikan reward dan poin-poin pembelajaran, situasi kelas menjadi ribut. Situasi kelas menjadi sangat ramai dan waktu yang digunakan menjadi sangat lama. Bahkan, ada sekitar empat orang siswa yang berteriak di dalam kelas. Sementara itu, ada tujuh orang siswa lainnya sibuk bercerita dengan temannya dan tidak memperhatikan penjelasan. Terdapat beberapa siswa yang terlihat masih kebingungan dalam pembelajaran dengan menggunakan reward sehingga membutuhkan waktu yang cukup lama dalam menjelaskan kontrak reward yang disampaikan.

Pada pertemuan kedua siklus satu, peneliti kembali menggunakan kontrak dan poin-poin sebagai reward untuk menarik minat dan motivasi belajar siswa dalam mengikuti pembelajaran dengan membagi siswa ke dalam enam kelompok. Setiap kelompok beranggotakan lima orang siswa yang ditentukan oleh peneliti untuk melakukan kegiatan pembelajaran. Namun, hal yang ditemui masih sama pada pertemuan pertama, siswa pada pertemuan kedua masih ribut, tidak mau mendengar penjelasan peneliti di depan kelas dan sibuk mengobrol dengan temannya serta mengganggu temannya. Hanya ada beberapa siswa yang bersemangat dan termotivasi dengan menggunakan reward sebagai motivasi dan menarik minat belajar. Pertemuan ketiga siklus satu, peneliti mengulang kembali materi yang disampaikan pada pertemuan satu dan dua sebelum melakukan tes. Adapun hasil analisis kriteria hasil belajar siswa pada siklus I sebagai berikut.
Tabel 1. Analisis kriteria hasil belajar siswa pada siklus I

\begin{tabular}{|c|c|c|c|}
\hline $\begin{array}{c}\text { Nilai } \\
\text { Siswa }\end{array}$ & $\begin{array}{c}\text { Nilai } \\
\text { Huruf }\end{array}$ & $\begin{array}{c}\text { Fruekuensi } \\
\text { (Jumlah } \\
\text { siswa) }\end{array}$ & Kriteria \\
\hline $80-100$ & A & 8 & Baik Sekali \\
\hline $66-79$ & B & 11 & Baik \\
\hline $56-65$ & C & 7 & Cukup \\
\hline $40-55$ & D & 4 & Kurang \\
\hline $30-39$ & E & - & $\begin{array}{c}\text { Kurang } \\
\text { Sekali }\end{array}$ \\
\hline
\end{tabular}

Grafik 1. Hasil belajar siswa pada siklus I

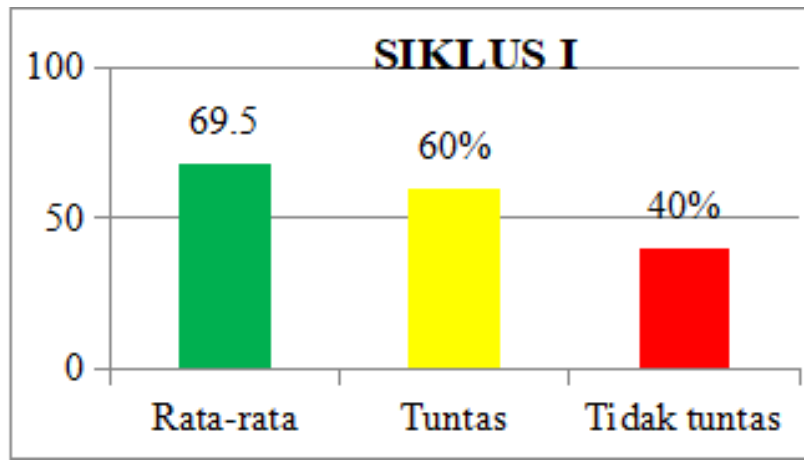

\section{Wawancara}

Dari hasil wawancara yang dilakukan oleh peneliti, selama belajar mengajar di kelas belum pernah sama sekali menggunakan reward dalam kegiatan pembelajaran. Hal itu membuat siswa merasa bosan, tidak berminat, dan tidak termotivasi dalam kegiatan pembelajaran tersebut.

\section{Observasi}

Hasil dari observasi pada siklus I pertemuan pertama, pertemuan kedua, dan pertemuan ketiga, selama tiga kali pertemuan, masih banyak masalah yang muncul. Banyak siswa yang tidak mau bergabung dengan kelompoksiswa lainnya dan banyak siswa yang ribut sehingga menciptakan suasana kelas yang kurang kondusif. Akibatnya, siswa tidak dapat berkonsentrasi dengan baik. 


\section{Refleksi}

Setelah melaksanakan kegiatan pembelajaran pada siklus I, peneliti melakukan refleksi terhadap proses kegiatan pembelajaran. Refleksi digunakan sebagai bahan pertimbangan untuk melanjutkan kegiatan pembelajaran pada siklus II. Berdasarkan data-data yang diperoleh, peneliti dapat menyimpulkan bahwa dari hasil tes evaluasi di akhir siklus menunjukkan hasil belajar pada siklus I dengan nilai rata-rata 69,5. Dari hasil tersebut belum menunjukkan ketercapaian kriteria ketuntasan minimum (KKM), yaitu e" 70. Oleh karena itu, dilanjutkan pada siklus II.

\section{Siklus II}

Siklus II terdiri atas 3 kali pertemuan. Waktu pembelajaran yang digunakan di setiap pertemuan adalah 70 menit. Waktu keseluruhan pembelajaran yang digunakan pada siklus II adalah 210 menit. Dalam penelitian ini, siklus II dilaksanakan dengan empat tahapan, yaitu sebagai berikut.

\section{Perencanaan}

Berdasarkan hasil refleksi pelaksanaan pada siklus I, telah diketahui bahwa belum ada peningkatan hasil belajar Bahasa Indonesia yang signifikan pada siswa dengan menggunakan reward. Oleh karena itu, perlu dilakukan perencanaan yang lebih matang pada siklus II. Peneliti memberikan arahan kembali kepada siswa dan memperbaiki pengolahan kelas. Peneliti menyusun kembali langkah-langkah perencanaan pembelajaran sebagai berikut:
a. menyiapkan rencana pelaksanaan pembelajaran (RPP),
b. menyiapkan soal evaluasi untuk melihat tingkat hasil belajar pada siklus II,
c. menyiapkan lembar wawancara,
d. menyiapkan lembar observasi, dan
e. menyiapkan reward.

\section{Pelaksanaan}

Pada tahap pelaksanaan ini dilakukan 3 kali pertemuan, yaitu pertemuan satu dan dua menyampaikan materi, sedangkan pada pertemuan ketiga melakukan tes hasil belajar siswa. Pada siklus II dilaksanakan tiga kali pertemuan, dua kali pertemuan untuk mengajarkan materi dan pertemuan ketiga tes. Selama pelaksanaan pembelajaran ada beberapa masalah yang dihadapi oleh peneliti, yaitu masih ada beberapa siswa yang sibuk berbicara dengan temannya pada saat peneliti menjelaskan materi. Akan tetapi, pada siklus ini siswa terlihat lebih aktif dan siap mengikuti pembelajaran daripada siklus I sebelumnya. Pada saat peneliti menyiapkan ruang kelas untuk memulai kegiatan pembelajaran masih ada beberapa siswa yang masih sibuk berbicara.

Akan tetapi, pada saat pembelajaran dimulai terlihat siswa sangat berminat dan termotivasi mengikuti kegiatan pembelajaran dan lebih siap mengikuti pembelajarannya. Pada pertemuan kedua, guru melanjutkan materi dari pertemuan pertama dengan menggunakan reward. Siswa terlihat antusias dan bersemangat dalam belajar dan lebih siap mengikuti pembelajaran serta siswa tidak mengalami kesulitan dibandingkan dengan siklus I, yakni siswa mengalami kesulitan dalam pembelajaran dan terjadi keributan antara kelompok satu dan lainnya. Pada pertemuan ketiga ini, peneliti mengulang kembali materi yang disampaikan pada pertemuan satu dan dua sebelum melakukan tes. Adapun analisis kriteria hasil belajar siswa pada siklus II sebagai berikut. 
Tabel 2. Analisis kriteria hasil belajar siswa pada siklus II

\begin{tabular}{|c|c|c|c|}
\hline $\begin{array}{c}\text { Nilai } \\
\text { Siswa }\end{array}$ & $\begin{array}{c}\text { Nilai } \\
\text { Huruf }\end{array}$ & $\begin{array}{c}\text { Fruekuensi } \\
\text { (Jumlah } \\
\text { siswa) }\end{array}$ & Kriteria \\
\hline $80-100$ & A & 20 & $\begin{array}{c}\text { Baik } \\
\text { Sekali }\end{array}$ \\
\hline $66-79$ & B & 6 & Baik \\
\hline $56-65$ & C & 4 & Cukup \\
\hline $40-55$ & D & - & Kurang \\
\hline $30-39$ & E & - & $\begin{array}{c}\text { Kurang } \\
\text { Sekali }\end{array}$ \\
\hline
\end{tabular}

Grafik 2. Hasil belajar siswa siklus II

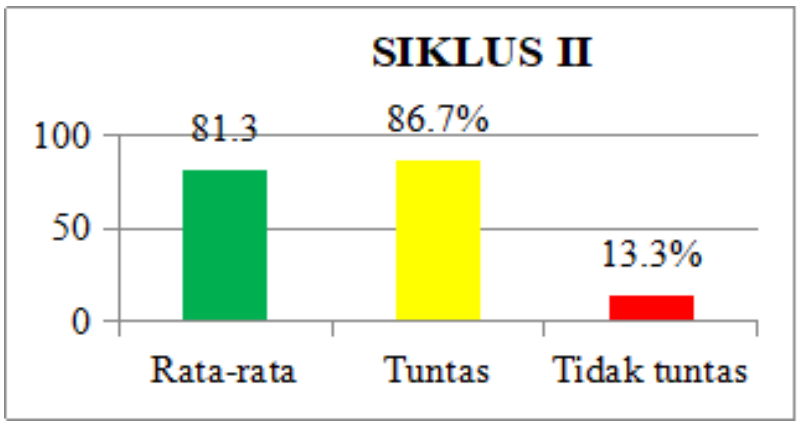

\section{Wawancara}

Dari hasil wawancara yang dilakukan oleh peneliti, selama belajar menggunakan reward, kegiatan pembelajaran membuat siswa termotivasi dan aktif dalam kegiatan pembelajaran tersebut. Hal ini menunjukkan ada kemajuan dalam tindakan yang dilakukan oleh peneliti.

\section{Observasi}

Hasil dari observasi pada siklus II pertemuan pertama, pertemuan kedua, dan pertemuan ketiga terlihat lebih semangat dan siap dalam mengikuti kegiatan pembelajaran yang sedang berlangsung. Kemudian, peneliti melanjutkan dengan menjelaskan materi dalam penerapan pembelajaran menggunakan reward.

\section{Refleksi}

Setelah melaksanakan kegiatan pembelajaran pada siklus II, peneliti melakukan refleksi terhadap proses kegiatan pembelajaran. Refleksi ini digunakan sebagai bahan pertimbangan untuk melanjutkan kegiatan pembelajaran. Berdasarkan datadata yang diperoleh, peneliti dapat menyimpulkan bahwa dari hasil tes evaluasi di akhir siklus ini menunjukkan bahwa hasil belajar pada siklus II mengalami peningkatan dan hasil ketuntasan belajar siswa kelas IV SDN 024 Samarinda Utara telah mencapai $81,33 \%$. Dari hasil tersebut penelitian dinyatakan berhasil dan penelitian pun dihentikan.

\section{Keterbatasan Penelitian}

Keterbasan selama penelitian tindakan kelas (PTK) yang dialami dalam penelitian ini adalah masalah pertama sekolah yang berdekatan dengan rumah-rumah penduduk, masalah kedua penguasaan kelas, masalah ketiga ada beberapa siswa yang sulit diatur di dalam proses pembelajaran, dan masalah keempat pada saat pembagian kelompok ada siswa yang tidak mau berkelompok dengan teman kelompoknya.

\section{PENUTUP}

Berdasarkan hasil penelitian, dapat disimpulkan bahwa pembelajaran menggunakan reward pada pelajaran Bahasa Indonesia dapat meningkatkan hasil belajar siswa kelas IV SDN 024 Samarinda Utara pada tahun pembelajaran 2019/2020. Hal ini dapat dilihat dari ketuntasan belajar pada siklus I dan siklus II hingga pada akhirnya di siklus II menjadi 81,3\% atau sama dengan di atas kriteria ketuntasan minimum (KKM) yang telah diberikan sebelumnya.

Akhirnya, dalam penelitian ini memunculkan saran bagi guru yang diharapkan dapat menggunakan pembelajaran yang 
menarik, kreatif, dan aktif secara tepat dalam kegiatan belajar mengajar sehingga dapat menciptakan rasa senang kepada siswa dalam pembelajaran. Sementara itu, bagi siswa diharapkan lebih aktif dan kreatif saat proses pembelajaran sehingga dapat meningkatkan prestasi belajarnya di sekolah.

\section{DAFTAR PUSTAKA}

Anwar, M. 2015. Filsafat Pendidikan. Jakarta: Kencana.

Arikunto, S., Suhardjono, dan Supardi. 2016. Penelitian Tindakan Kelas (2nd Ed.). Jakarta: Bumi Aksara.

Daryanto. 2011. Penelitian Tindakan Kelas dan Penelitian Tindakan Sekolah. Yogyakarta: Gava Media.

Hamalik, Umar. 2013. Proses Belajar Mengajar. Jakarta: Bumi Aksara.

Hidayah, Nurul. 2015. Penanaman Nilai-

Nilai Karakter dalam Pembelajaran Bahasa Indonesia di Sekolah Dasar. Jurnal Pendidikan dan Pembelajaran Dasar Terampil. Vol 2, No 2 (2015). Lampung: Universitas Islam Negeri Raden Intan Lampung.

Badan Pengembangan dan Pembinaan Bahasa, Kementerian Pendidikan dan Kebudayaan. 2016. Kamus Besar Bahasa Indonesia Edisi V. Jakarta.

Subakti, Hani. 2017. Pengembangan Bahan Ajar Menulis Slogan dan Poster dengan Pendekatan Proses Siswa Kelas VIII SMP Syaichona Cholil Samarinda. Jurnal Ketatabahasaan dan Kesusastraan LOA. Vol 12, No 2 (2017). Samarinda: Kantor Bahasa Kalimantan Timur.

Sudjana, Nana. 2016. Penilaian Hasil Proses Belajar Mengajar. Bandung: Remaja Rosdakarya.

Sugiyono. 2015. Metode Penelitian Pendidikan. Bandung: Alfabeta.
Susanto, A. 2016. Teori Belajar dan Pembelajaran di Sekolah Dasar. Jakarta: Kencana.

Sutrisno. 2019. Pemanfaatan KBBI V Daring dalam Pengajaran Bahasa Indonesia di Sekolah Dasar. Jurnal Ketatabahasaan dan Kesusastraan LOA. Vol 14, No 2 (2019). Samarinda: Kantor Bahasa Kalimantan Timur.

Wijaya, C., dan Syahrum. 2013. Penelitian Tindakan Kelas. Melejitkan Kemampuan Penelitian Untuk Meningkatkan Kualitas Pembelajaran Guru. Bandung: Citapustaka Media Perintis. 